\title{
UNA CIRUJANO OCULISTA EN EL SIGLO XVIII: VICTORIA DE FELIX
}

\author{
MÁRQUEZ-DE-ARACENA-DEL-CID R ${ }^{1}$
}

Hace dos años se publicó en esta revista un artículo en el que se daban algunas pinceladas sobre la existencia de la cirujano oculista Victoria de Félix, invitando a que se continuase dicho estudio (1). Recogí el guante y, en cuanto pude, me interesé por esta dama desconocida hoy en día pero de tanta fama en su tiempo que hasta el Príncipe de la Paz la señala entre los ingenios que descollaron en el plano científico y dieron lustre a la España de Carlos IV (2).

De origen francés y humilde, nació sobre 17731774 en Nevers, hija de Ana Juillien y Pedro de Félix. Parece ser, que tras la muerte de su padre, madre e hija emigraron a España donde tenían algún familiar. Entre ellos Lorenzo Lemayre, cirujano oculista especialmente diestro en la extirpación de la catarata. La primera referencia a este doctor es del año 1776 (Gazeta de Madrid -GM, en adelante-10/X/1776). Éste, como casi todos los franceses que llegaban a Madrid, se instaló en la calle Caballero de Gracia pasando a la calle Hortaleza al poco tiempo. Diez años después, en 1787, tuvo que soportar un juicio sobre excesos en el ejercicio de su profesión (3).

Nuestra protagonista y su madre, al llegar a España, fueron a Madrid buscando a sus compatriotas que solían residir en el barrio de San Martín instalándose en la calle del Espíritu Santo, n. ${ }^{\circ}$ 15, cuarto principal. Don Lorenzo, impresionado por la inteligencia y destreza de Victoria la tomó como discípula y le enseñó todo lo referente a Oftalmología. Tal era su destreza que a los 19 años ya operaba por sí sola, hecho que destacó la GM (Publicación semioficial de entonces): "ha hecho en Madrid la extracción de cataratas a toda clase de gentes. El primor seguridad, desinterés y acierto con que esta joven ha executado dichas operaciones y su agilidad en una edad tan tierna, merecen general aplauso" (GM 29/I/1793). La prensa madrileña destaca su pulso y serenidad durante las intervenciones, operando: fístulas lagrimales, pterigios, triquiasis $\mathrm{y}$ cataratas. Su fama se extiende ampliándose su clientela hasta la Corte: un criado del Marqués de Escolano, dos religiosos del convento de San Gil, un cirujano de las montañas de Santander e incluso la esposa de Mr. Royer, dentista de Carlos IV, entre otros. Siendo llamada desde diferentes puntos de la Península. En 1973 acude a Ocaña a intervenir a un matrimonio ciego de cataratas dobles y a Cartagena donde atiende a su Gobernador, D. Alfonso de Alburquerque, por el mismo problema (GM 6/12/1793), todavía iría con ella su maestro y tío. A los pocos meses se vuelve anunciar su vuelta a Madrid con éxito tras curar al Gobernador y a su madre (GM 21/03/1794). No deja de pasar por Murcia donde realiza muchas operaciones a ciegos antiguos, mozos y ancianos que han salido perfectamente curados (GM 6/12/1793). Se le califica como «diestra facultativa». Tras compartir la misma consulta con D. Lorenzo Lamayre, a éste le abandona su buena fortuna pues se cambia de domicilio y consulta a la calle del Pez, num. 1 en 1795 (GM 24/09/1795) y en 1796 a la del Rincón (GM 2/02/1796) llegando a la pobreza y a la indigencia, teniendo que ser recogido, junto a su hija natural de tres años, por el Barón de Isus en su casa (4).

Mientras, Victoria de Félix, con la ayuda de su madre, sigue realizando todo tipo de operaciones sobre los ojos. Se hace muy popular y cura a los pobres de caridad. Dicho año se desplaza a Cádiz a curar un regidor perpetuo D. Sebastián Pérez (GM 18/03/1796), у a otro personajes de estafilomas, pterygium y cataratas (GM 18/11/1796). Tal es su conocimiento y fama que en 1797 ya había conseguido el título de «oculista con Real permiso» (GM 09/05/1797).

Tal eran sus habilidades que algún paciente no dudó en dejarle una mensualidad vitalicia. Don Sebastián Pérez, regidor Perpetuo y Alcalde Mayor de Veracruz, tras ser curado de los ojos le dejó 240 reales de mensualidad en bienes hipotecados $(2,5)$.

\footnotetext{
${ }^{1}$ Facultad de Medicina. Universidad de Sevilla. Sevilla. España. E-mail: rafael_marquez@fremap.es
} 
A los 23 años se había extendido tanto su fama que personajes de todo tipo declaran públicamente haber sido curados de los ojos por esta joven oculista tras consultar a los mejores facultativos de la Corte. No sólo cura a personas acomodadas sino también a gente humilde y sin medios: se pone en conocimiento "para que no careciese deste beneficio ni de caridad y desinterés con que esta hábil mujer trata y cura a los enfermos de todas clases, asi ricos como pobres» (GM 17/10/1797). Tal reputación obliga a mejorar su lugar de atención cambiando de domicilio y consulta de la calle Santo Espíritu a la plazuela de San Idelfonso, n. 13, cuarto principal (GM 17/07/1799). El ejercicio de tal profesión, reservada a hombres y que imprime carácter, no hizo que Victoria olvidase los asuntos del corazón. Contrajo matrimonio el 22 de marzo de 1800 con un compatriota, D. Gaspar de Didier Mevolhon, capitán retirado de caballería agregado a Madrid $(2,6)$, con el que había realizado las capitulaciones matrimoniales cuatro años antes $(2,7)$. Por su carta de dote, sabemos que Victoria no poseía bienes considerables (29.608 reales). Entre otras, poseía varias representaciones religiosas y llevaba al matrimonio un considerable y coqueto vestuario de ajuar femenino, valorado en 12.000 reales (8). A los pocos meses del enlace murió su madre sin dejar bienes (9).

Sus obligaciones conyugales para nada le impidieron el ejercicio de su profesión. A los 20 días de su boda «continuaba la curación de las enfermedades de los ojos y ha conseguido dar últimamente la vista a muchas personas» (GM 11/04/1800). No sólo ejerció su profesión sino que tuvo interés en mejorar sus habilidades «ha perfeccionado de tal modo la operación de la catarata, que rara vez se le desgracia algún enfermo» (GM 07/04/1801). En 1802 cambia de domicilio a la calle alta de Fuencarral, en aquel año se titula «oculista con Real privilegio».
Doña Victoria permanecería en España ejerciendo su profesión hasta 1808. Durante el período convulso de la ocupación francesa, marchó con su marido a Sisteron, en Francia, localidad natural de éste, donde vivían de una pensión que recibía como teniente coronel retirado (10), volviendo sólo en algunas ocasiones para reclamar ante los tribunales ciertos pagos pendientes. La última vez que pisó suelo español pudo ser en el año 1822 (2). Probablemente continuó ejerciendo su profesión en su país natal. Siendo un caso único de la España Ilustrada.

\section{BIBLIOGRAFÍA}

1. López de Letona C. Cirujanos oculistas en la Gaceta de Madrid. Arch Soc Esp Oftalmol 2007; 82: 523-524.

2. Demerson P. Una mujer cirujano en tiempos de Carlos IV: Victoria de Félix. Anales del Instituto de Estudios Madrileños; 1973, 9: 415-426.

3. Archivo de la Real Chancillería de Valladolid. Causas Secretas, caja 23,1. Disponible en: http://www.mcu.es/ archivos/docs/MC/folleto_chancill_valladolid_web.pdf

4. Declaración de pobre que en 9 de abril hizo don Lorenzo Lemaire. Archivo de Protocolos Madrid, escribanía Moretón. 1796, fol. 52-53v.

5. Archivo Histórico provincial de Cádiz. Archivo Protocolos Cádiz. Escribano Cayetano Vidal, 1796, 15 de marzo.

6. Archivo Parroquial de S. Martín, Madrid. Libro de bautismos, matrimonios y difuntos castrenses, 1800, f. 53v.

7. Archivo de Protocolos Madrid. Escribanía Moretón. 1796. Leg. 21257 f. 67-70.

8. Archivo de Protocolos Madrid. Escribanía Moretón. 1796, Leg. 21257, f 71-74. Carta de dote de doña Victoria de Félix, 22 de abril de 1796.

9. Archivo de Protocolos Madrid. Escribanía Moretón. 1796, Leg. 21258, f 161. 12-XI-1800.

10. Bulletin des Lois du Royaume de France, 7 serie. Tomo Neuviéme. Contenan les Lois et Ordennaces rendues pendant le second semestre del ánée 1819. No 292 à 336. Paris, Févier 1820. n. 7590 p.400. 